\title{
Pengenalan Manajemen Keuangan Usaha Kecil dan Menengah
}

\author{
Baiq Adriani Ulfa ${ }^{1}$, Ikang Murapi ${ }^{2}$, Phyta Rahima ${ }^{3}$, R. Ayu Ida Aryani ${ }^{4}$, Suriati ${ }^{5}$ \\ baiqadrianiulfa@universitasbumigora.ac.id ${ }^{1}$, \\ ikangmurapi11@universitasbumigora.ac.id², phytarahim@gmail.com ${ }^{3}$, \\ ayu.aryani@universitasbumigora.ac.id ${ }^{4}$, suriyati@universitasbumigora.ac.id ${ }^{5}$
}

1,2,3,4,5 Universitas Bumigora

\begin{tabular}{ll}
\hline Article History: & Abstract: Desa Langko merupakan salah satu desa yang \\
Received: & ada di Kecamatan Lingsar, Kabupaten Lombok Barat, \\
Revised: & Provinsi Nusa Tenggara Barat salah satu desa yang \\
Accepted: & dijadikan Project sebagai desa Pariwisata Pemerintah \\
& Provinsi NTB. Desa yang terletak di bagian barat Pulau \\
Keywords: Manajemen & Lombok ini memiliki semboyan geger girang genem hal ini \\
keuangan, UKM & juga selaras dengan kegiatan-kegiatan yang dilakukan \\
& masyarakatnya yang sebagian besar memiliki olahan \\
& produk-produk rumahan. Hal tersebut terbukti dengan apa \\
& yang terjadi, banyak sekali rumah tangga yang memiliki \\
& usaha sebagai pembuat keripik olahan, keripik singkong, \\
& keripik tempe. wedang jahe, beepolen, madu dan gula \\
& merah. Dengan semakin majunya Usaha Kecil dan \\
& Menengah (UKM) dan berdampak pada persaingan yang \\
& semakin ketat, maka diharapkan UKM yang berada di \\
& Desa Langko ini dapat berkembang dan meningkatkan \\
& kualitas produknya. Berdasarkan hal tersebut maka \\
diperlukan suatu metode manajamen keuangan yang & mudah untuk dipahami dan juga diterapkan oleh Usaha \\
& Kecil dan Menengah (UKM) di Desa Langko
\end{tabular}

\section{Pendahuluan}

Secara umum dalam organisasi setiap aktivitas manajemen diarahkan untuk mencapai tujuan organisasi secara efektif dan efisien. Manajemen adalah proses bekerja sama antara individu dan kelompok serta sumber daya lainnya dalam mencapai tujuan. Tujuan dari fungsi manajemen dengan cara yang terbaik yaitu efisiensi waktu dan uang, dan menggunakan fasilitas dengan tepat. Aktivitas manajerial hanya ditemukan dalam wadah sebuah organisasi, baik organisasi bisnis, sekolah dan juga lainnya (Syafruddin;2005).

Manajemen usaha kecil relatif berbeda dengan manajemen usaha dengan skala besar. Perbedaannya antara lain pada perusahaan besar dan mapan antar fungsi dan tugas manajer telah dipilah-pilah sedemikian rupa sesuai strategi dan struktur organisasi. Pada usaha kecil dimana seluruh sumberdaya sangat terbatas, fungsi dan manajer berbaur menjadi satu karena terbatasnya sumber daya. Manajemen keuangan diartikan sbagai seluruh aktivitas atau kegiatan perusahaan yang berhubungan dengan upaya untuk mndapatkan dana perusahaan dengan meminimalkan biaya serta upaya penggunaan dan pengalokasian dana tersebut secara efisien dalam memaksimalkan nilai perusahaan. (Alteza,2012). 
UKM (Usaha Kecil dan Menengah) merupakan istilah yang mengacu pada suatu jenis usaha yang didirikan pribadi dan memiliki kekayaan bersih paling banyak Rp. 200.000.000 (belum termasuk bangunan) (Nayla; 2014). Beberapa alasan yang menjelaskan posisi starategi UMKM di Indonesia (Sujarweni;2019); pertama, UMKM tidak memerlukan modal yang besar sebagaimana perusahaan besar sehingga pembentukan usaha tidak sesulit usaha besar. Kedua, tenaga kerja yang diperlukan tidak menuntut penidikan formal tertentu. Ketiga, sebagian besar berlokasi di pedesaan dan tidak memerlukan infrastruktur sebagaimmana perusahaan besar. Keempat, UMKM terbukti memiliki ketahanan yang kuat ketika Indonesia dilanda krisis ekonomi.

Usaha Kecil Menengah atau UKM merupakan bisnis yang juga memerlukan pengelolaan keuangan yang baik. Setiap bisnis akan membutuhkan pengelolaan keuangan yang tepat agar bisnis tetap bisa berjalan dengan lancar. Setiap pelaku usaha kecil menengah (UKM) perlu menerapkan manajemen keuangan yang baik, minimal pelaku UKM mempunyai buku catatan kas masuk dan juga kas keluar. Manajemen keuangan tidak hanya sekedar bagaimana cara mengelola uang kas, tetapi lebih kepada bagaimana cara mengelola keuangan untuk menghasilkan keuntungan serta memanfaatkan sumber modal demi untuk membiayai usaha, walaupun sederhana sehingga UKM tetap perlu menerapkan manajemen keuangan.

Keluar masuknya uang tentu harus didasarkan pada tujuan yang bisa menghasilkan keuntungan. Di sinilah peran penting dari manajemen keuangan. Keberhasilan sebuah usaha dapat terlihat dari kemampuan para pengelola dalam mengelola keuangan dan memanfaatkan peluang secara maksimal sehingga menghasilkan return atau imbalan sesuai harapan. Merencanakan manajemen keuangan tentu sangat bermanfaat untuk mengarahkan dan mengendalikan keuangan atau aliran kas suatu usaha. (Musthafa.2017).

Saat ini masih banyak UKM yang belum memisahkan uang usaha dan uang pribadi, begitupula dengan UKM Desa Langko kerap tidak melakukan pemisahan uang usaha dan uang pribadinya. Pemilik UKM terbiasa dengan mengambil laba dari penjualan produk dan langsung menggunakannya untuk kepentingan pribadi seperti membeli kebutuhan seharihari, pembayaran cicilan dan banyak lagi.

Mindset kebanyakan pelaku usaha yang kami temukan adalah tidak memikirkan perkembangan usahanya. Ketika laba diambil terus menerus tanpa ada pencatatan, usaha akan mengalami stagnansi dan lama-kelamaan usaha dapat mengalami kerugian. Oleh karena itu pengetahuan akan pengetahuan keuangan sangatlah penting untuk dipelajari. Definisi dari manajemen keuangan adalah kegiatan manajemen yang berfungsi untuk mengelola aset-aset maupun dana. Dengan melihat permasalahan yang ada saat ini, maka UKM Desa Langko memerlukan pengetahuan mengenai manajemen keuangan UKM untuk membantu dan mengontrol keuangan usahanya. Pengabdian yang dilakukan disini yaitu membantu mengenalkan manajemen keuangan UKM agar dapat mengontrol keuangan usaha.

\section{Metode}

Pengabdian ini dilaksanakan pada UKM di Desa Langko metode ceramah dan diskusi. Penentuan peserta yang dilaksanakan dalam penyuluhan pengenalan manajemen 
keuangan adalah pengusaha UKM yang usahanya sudah lama. Kegiatan ini akan dilaksanakan dalam satu hari. Penentuan hari ditentukan oleh Kepala Desa Langko .

Penetapan lokasi pengabdian ini merupakan suatu upaya untuk meningkatkan kinerja keuangan UKM yang sudah terdaftar di kantor desa Langko sehingga perkembangannya dapat diketahui dan dipantau dengan mudah. Harapannya peserta pelatihan dapat menularkan ilmu yang didapatkan kepada pelaku UKM lain yang berada di sekitarnya.

Adapun sistematika pelaksanaan kegiatan pengabdian ini adalah sebagai berikut :

1. Metode Ceramah.

Peserta diberikan motivasi, gambaran umum mengenai manajemen keuangan UKM dan peran penting akuntansi bagi UKM.

2. Metode Diskusi

Peserta diberikan kesempatan untuk menduskusikan permasalahan yang berkaitan dengan keuangan UKM yang selama ini dihadapi.

\section{Hasil}

Acara dimulai tepat pukul 09.30 WITA, diawali dengan pembukaan oleh Kepala Desa Langko dan sambutan oleh ketua tim pengabdian. acara dilanjutkan dengan pemberian materi bertema "Pengenalan Manajemen Keuangan Usaha Kecil Menengah (UKM)" yang disampaikan oleh Baiq Adriani Ufa, SE.,M.Ak dan R. Ayu Ida Aryani,SE.,M.Ak. Peserta mengikuti penyuluhan dengan sangat antusias, hal ini terlihat ketika pada sesi tanya jawab peserta banyak mengajukan pertanyaan berkaitan dengan pentingnya manajemen keuangan. Selama penyuluhan hari pertama ini, peserta mendapatkan fasilitas dari panitia berupa snack. Secara keseluruhan penyuluhan ini berjalan dengan lancar.

Pelatihan dilaksanakan selama satu hari pada tanggal 7 Maret 2020 di Kantor Desa Langko. Peserta yang diundang dalam pelatihan sebanyak 28 pemilik UKM. Berbagai jenis usaha yang mereka lakukan antara lain: keripik singkong, keripik tempe. wedang jahe, beepolen, madu dan gula merah.

Dalam pelaksanaannya penyuluhan ini dapat dibilang sukses, peserta sangat antusias mengikuti kegiatan ini hingga selesai. Pertanyaan dari peserta sering kali muncul di tengah para pemateri menyampaikan materi pelatihan.

Dalam pengabdian ini kami memberikan gambaran kepada pihak terkait peserta penyuluhan yaitu pelaku Usaha Kecil dan Menengah (UKM) tentang manajemen keuangan UKM dan beberapa staff Kantor Desa Langko sebagai berikut (Anitasari, 2017):

1. Pisahkan uang usaha dengan uang pribadi. Memisahkan uang pribadi dan uang usaha dapat mengetahui pengeluaran serta pemasukan usaha dengan jelas. Dan masih ada beberapa manfaat lainnya yang bisa dirasakan saat disiplin dalam menggunakan uang usaha dan uang pribadi secara terpisah, seperti:

- Pembukuan keuangan menjadi lebih efektif dan efisien

- Uang untuk modal usaha akan terlindungi karena terdapat catatan transaksi dengan jelas

- Dapat diketahui apakah usaha sudah menguntungkan atau belum, sehingga lebih mudah untuk mengambil keputusan menyangkut usaha 
2. Perencanaan penggunaan uang. Sesuaikan rencana pengeluaran dengan target-target penjualan dan penerimaan kas. Evaluasi terhadap rencana-rencana belanja yang menggunakan modal, jika tidak memberikan manfaat dalam meningkatkan penjualan atau menurunkan biaya-biaya. Lakukan analisa untung-rugi untuk meyakinkan bahwa penggunaan uang usaha tidak akan sia-sia dan memberikan return yang menguntungkan.

Perencanaan merupakan bagian penting dalam membangun perusahaan. Jika sudah direncanakan dengan matang, kemungkinan rugi akan lebih kecil. Tentunya perencanaan bagaimana produk terjual keras di pasaran juga harus diperhitungkan agar bisnis tidak merugi.

3. Membuat buku catatan keuangan. Usaha UKM berada pada taraf sedang berkembang, namun untuk manajemen keuangannya tidak cukup dikelola berdasarkan ingatan, melainkan dengan catatan yang lengkap. Minimal, sebuah usaha wajib memiliki buku kas yang mencatat keluar masuknya uang. Lakukan pencocokan saldo dengan catatan keuangan usaha dan pastikan tidak ada perhitungan yang tertinggal.

Setiap transaksi harus dicatat dengan detail agar tidak terjadi kesalahan dalam pelaporan keuangan. Transaksi bisnis yang dicatat dengan tepat juga akan memudahkan proses perhitungan laba dan rugi. Setiap bukti transaksi akan menjadi catatan tentang berapa banyak produk yang terjual dan berapa keuntungan yang didapat.

4. Hitung keuntungan dengan benar. Menghitung keuntungan dengan tepat sama pentingnya dengan menghasilkan keuntungan itu sendiri. Namun yang sering terlupakan dari penghitungan keuntungan ini adalah kesalahan terkait pengeluaran biaya yang dikeluarkan perusahaan. Jika perusahaan memiliki kesalahan pencatatan pembiayaan, maka secara tidak langsung hal ini akan berpengaruh pada kesalahan perhitungan keuntungan yang didapat. Pencatatan pembiayaan yang dihitung secara cermat memudahkan pemilik usaha untuk mengontrol keuangan dan transaksi yang terjadi dalam sebuah bisnis.

5. Awasi harta, hutang dan modal. Periksa persediaan di gudang secara berkala dan dipastikan semuanya dalam keadaan lengkap dan baik. Buatlah sistem administrasi yang memadai untuk mengontrol hal tersebut. Lakukan hal yang sama terhadap piutang-piutang kepada pembeli dan tagihan-tagihan dari supplier. Jangan sampai terdapat tagihan macet atau pembayaran ganda kepada supplier tanpa sepengetahuan perusahaan. Buatlah pencatatan keuangan yang baik.

6. Sisihkan keuntungan untuk pengembangan usaha. Meskipun bisnis telah berjalan lancar bukan berarti semua keuntungan berhak digunakan di luar kepentingan usaha. Sebagai UKM, maka strategi manajemen keuangan yang penting adalah terkait pengembangan. Rencanakan investasi tambahan, kenali bidang-bidang yang masih menguntungkan dan dapat memperluas nilai aset perusahaan. Gunakan keuntungan secara bijak dan sisihkan sebagian untuk memperbesar perusahaan. 


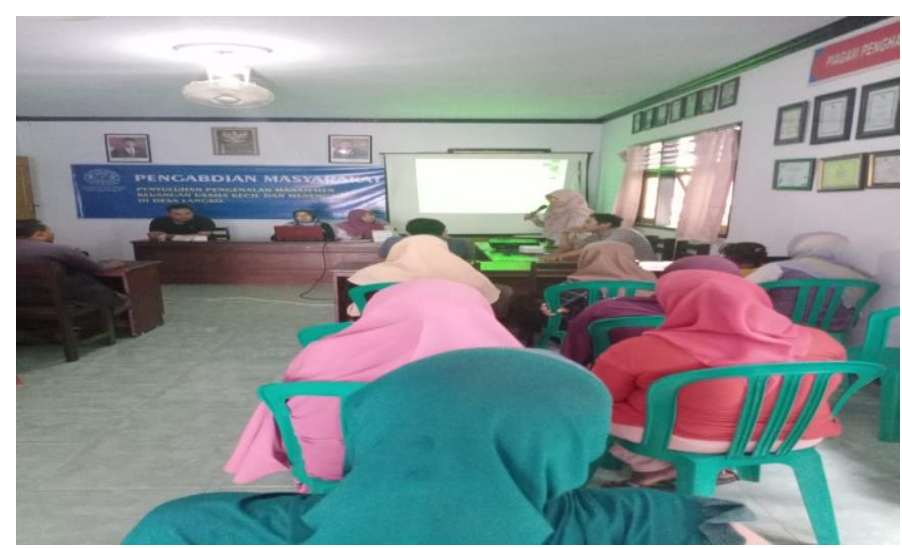

Gambar 1. Dokumentasi Pengabdian

\section{Diskusi}

Pelaksanaan penyuluhan berjalan dengan lancar. Materi yang diberikan adalah pengenalan atau pendahuluan mengenai manajemen keuangan. pemateri memberikan penjelasan pentingnya manajemen keuangan bagi UKM. Sebagian besar audiens belum mengerti fungsi manajemen keuangan, bahkan sebagian besar peserta pelatihan menganggap bahwa manajemen keuangan adalah bidang yang rumit, susah, merepotkan, menghabiskan waktu. Materi pertama ini diisi dengan penguatan pentingnya manajemen keuanganga bagi UKM. Pada sesi ini terjadi diskusi yang menarik antara audiens dengan pemateri mengenai konsep dasar usaha.sss

Beberapa audiens memiliki persepsi berbeda tentang usaha. Berdasarkan diskusi konsep manajemen keuangan ini akhirnya diperoleh pemahaman konsep manajemen keuangan setelah diperoleh kesepakatan tentang manajemen keuangan.

\section{Kesimpulan}

Artikel Pengabdian kepada masyarakat ini membahas terkait Pengenalan Manajemen Keuangan Usaha Kecil dan Menengah (UKM) maka dapat diambil kesimpulan bahwa melalui pelatihan ini dapat menambah pengetahuan peserta penyuluhan pihak terkait seperti pelaku UKM dalam pemahaman manajemen keuangan UKM untuk meningkatkan kinerja keuangan Usaha Kecil dan Menengah (UKM). Semua peserta antusias mengikuti acara hingga selesai dan merasakan manfaat penyuluhan bagi kemajuan usaha mereka.

\section{Pengakuan}

Penulis mengucapkan terima kasih kepada Prodi Akuntansi, Prodi IImu computer dan Prodi Sistem Informasi Universitas Bumigora Mataram serta pihak Lembaga Pendidikan dan Pembinaan Manajemen (LPPM) Universitas Bumigora Mataram yang telah mendukung kegiatan Pengabdian kepada Masyarakat ini, tim Pengabdian yang membantu pelaksanaan di lapangan, Rektor dan Wakil Rektor serta Dekan yang telah mendukung kegiatan ini, serta pihak lain yang mendukung kegiatan ini hingga penulisan artikel ini selesai. 


\section{Daftar Pustaka}

Alteza, Muniya. 2012" Manajemen Keuangan Praktis bagi UMKM’. Universitas Negeri Yogyakarta Musthafa.2017. Manajemen Keuangan. ANDI-Yogyakarta

Nayla, Akifa P. 2014. Komplet Akuntansi Untuk UKM dan Waralaba. Laksana. Yogjakarta

Nuraini Anitasari 24 May 2017. Cara Jitu Mengelola Keuangan Usaha Kecil dan Menengah. https://zahiraccounting.com/id/blog/mengelola-keuangan-ukm/

Sujarweni, V. Wiratna. 2019. Akuntansi UMKM (Usaha Mikro Kecil Menengah). PT. Pustaka Baru. Yoyakarta.

Syafaruddin, Manajemen Lembaga Pendidikan Islam (Jakarta: Ciputat Press,2005), h. 41. 